Reprod. Nutr. Dévelop., 1988, 28 (5), 1357-1362

\title{
The epithelial mounds of the distal epididymal tubule (zone 9) after new microsurgical models of tubulo-vasostomy. Study in the rat
}

\author{
G. TRITTO (1)
}

Institute of Clinical Surgery (Division of Urology), University of Bari, Italy.

\section{Introduction.}

Different microsurgical models have been realized in rat in order to obtain end-to-end or side-to-end tubulo-vasostomies (Tritto et al., 1983, 1984, 1985).

These experimental models are based on a new principle in reconstructive microsurgery of the epididymis: the intraserous unfolding of the epididymal tubule (Tritto et al., 1987). With the unrolling procedure realized on the distal epididymal tubule (zone 9 according to Zunke and Gossrau, 1981), the peeling of the peritubular capillary network (having a " deferential type " of organization : Suzuki, 1982) that encircles each individual tubular coil, and the damaging of the thin stromal atmosphere and its cellular components impair the interstitial compartment of the cauda epididimidis.

In spite of extensive reports on the interstitial spaces in testis (Fawcett et al., 1973), where numerous trypan blue-labelled macrophages are observed in rat (Niemi et al., 1986), or even sometimes mistaken for Leydig cells (Christensen, 1975), the interstitial compartment of the epididymis has been completely neglected. The macrophagic population of endocrine organs as testis, ovary and pancreatic islets represents a numerically dominant component of the interstitium (20\%) compared to other non-endocrine organs (2-5\%) and displays considerable functional heterogeneity and specific surface antigen expression (F4/80 antigen positive cells) (Hume et al., 1984). It is considered that F4/80-positive macrophages form a resident network throughout the endocrine organs, representing a particular population of the macrophage constellation.

Recent observations (Tritto et al., 1986) also indicate that in the interstitial compartment of the rat epididymis, TB-loaded, PAS-positive cells, macrophagic in type, are present, representing $10-18 \%$ of all interstitial cells in young adult unmated rats. Usually the phagocytic cells occur individually and are scattered among the tubular oils.

( $\left.{ }^{1}\right)$ Personal address to whom all correspondance should be sent: Giuseppe Tritto, M.D. Via Ettore Carafa, 2970100 Bari, Italia. 
The spermatic granulomatous reaction developing around the site of tubulodeferential anastomosis after the above-mentioned microsurgical models evokes a new histo-pathological lesion of the epididymal epithelium, involving the interstitial macrophagic population described in this work.

\section{Material and methods.}

Three-month old unmated male Wistar albino rats, weighing $300 \mathrm{mg}$, were submitted to (1) end-to-end tubulo-vasostomy after intraserous proximal hemideferentectomy or subtotal deferentectomy, (2) side-to-end tubulo-vasostomy after intraserous proximal hemideferentectomy with the epididymal loop constituted by afferent and efferent branches.

In all these models we used the unfolding procedure of the distal epididymal tubule and its transposition into the serous coat of the vas deferens.

Rats were injected intraperitoneally with $1 \%(\mathrm{v} / \mathrm{v})$ trypan blue solution before sacrifice to quantify the distribution of resident interstitial macrophagic cells of the testis and the epididymis on seriated histological sections in O.M. Semithin sections, obtained after fixation in $1 \% \mathrm{OsO}$ and inclusion in Epon 812, were stained with toluidine blue, toluidine blue-pironine, PAS, Alcian Blue. Ultrathin sections, stained with uranyl acetate and lead citrate, were examined in a Zeiss EM 109 electron microscope at $80 \mathrm{kv}$.

\section{Results.}

The spermatic granulomatous reaction that developed on the anastomotic site of tubulo-vasostomies plugged the lumen in the initial phase, but canalized itself in a period of $1-3$ months.

The spermatic granuloma evoked the macrophagic reaction in the wall of the epididymal tubule throughout mobilization of the interstitial resident macrophages; the lymphatic channels of the serous coat of the removed vas deferens were enlarged: the engorgement of lymphatic sinusoids with immune cells and the margination of macrophages were common findings in this anatomo-pathological experimental situation.

In transverse sections the epithelium of the distal epididymal tubule presented a festooned appearance caused by particular epithelial formations, for the first time called «epididymal epithelial mounds" (bourgeons épithéliaux) (fig. 1). These epithelial hillocks had a central core supporting compact and spongy configurations : the compact aspect was characterized by close contact of the stored-up cells, while in the spongy aspect large intercellular spaces were evident. In the compact mound, the cellular population of the central core was represented to a great extent by clear cells in different stages of maturation and differentiation, with scanty cells of the immune response (fig. 2); in the spongy mound we found only macrophagic cells organized into intraepithelial macrophagic rosettes : the PAS-positive phagocitic elements were disposed all around degenerating cells and appeared to be engulfed by cellular components and epithelial debris (fig. 3 ). 


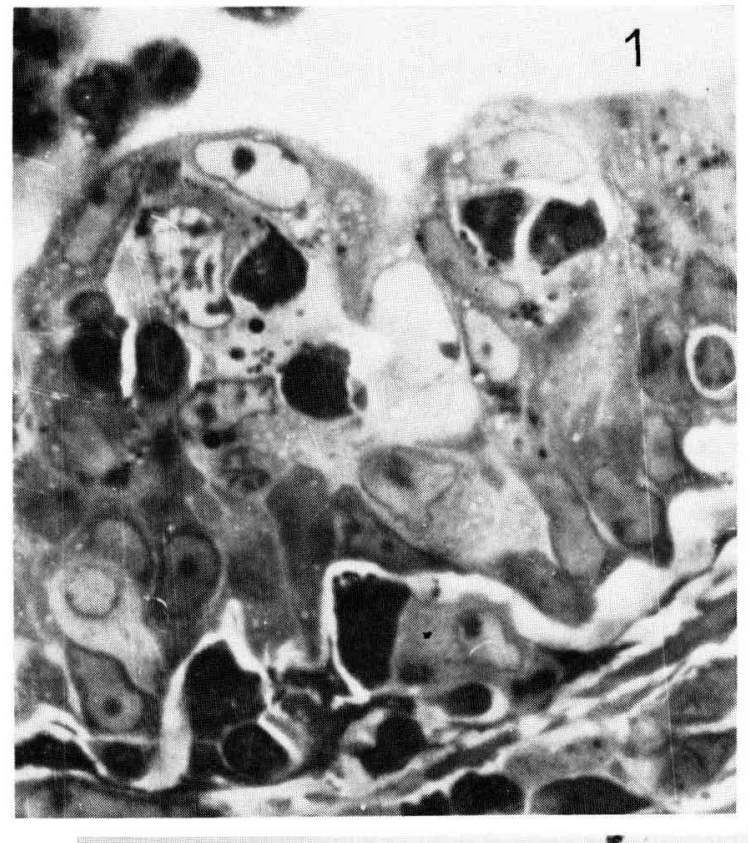

.

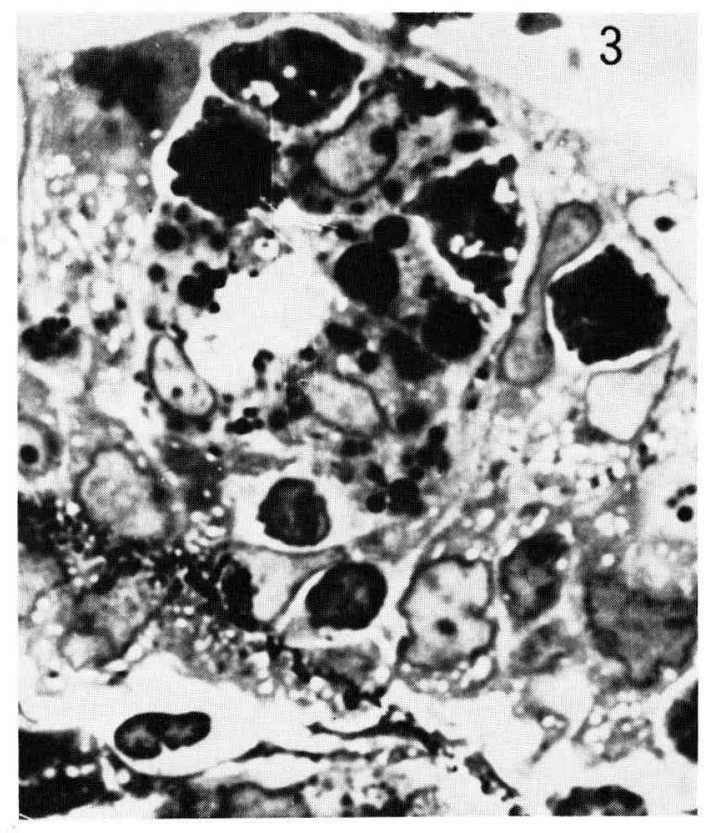

2

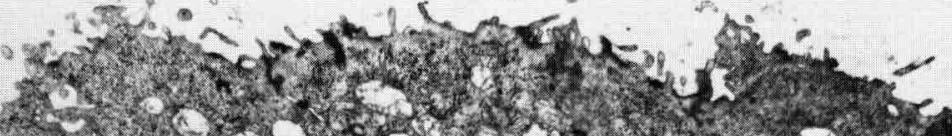

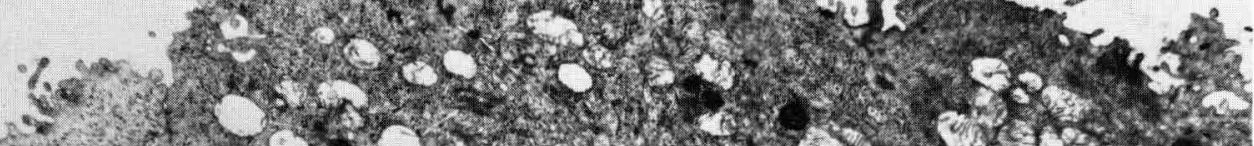

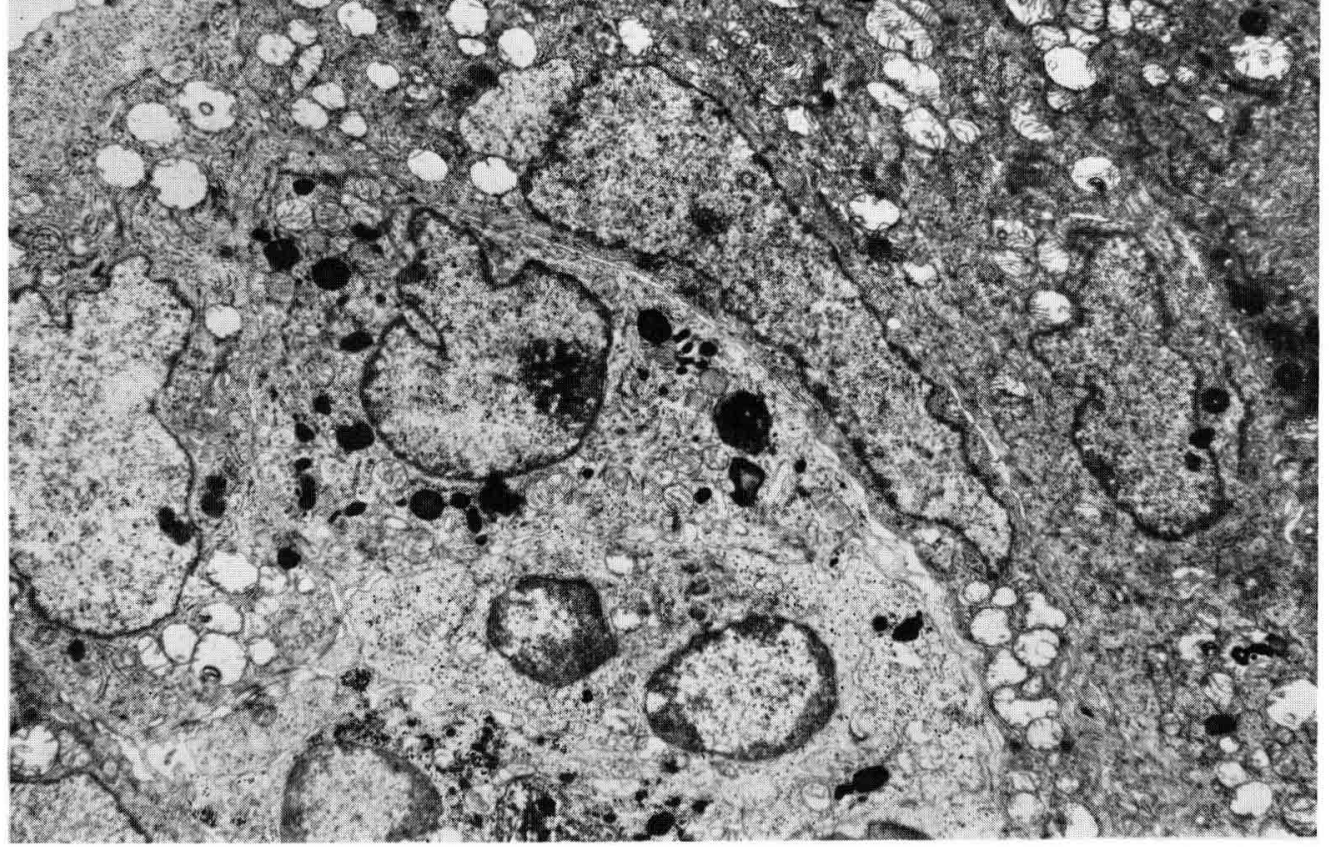

FIG. 1. - Typical epididymal epithelial mound. Semithin section. Toluidine blue-pronine staining.

FIG. 2. - Ultrastructure of a compact mound.

FIG. 3. - Macrophagic cel/s assembled in intraepithelial rosettes. 
All phases of the progression of the rosettes from the basal membrane to the apical surface of the epithelium were observed: the focal and progressive rise of the epithelium into a mound, the dislocation of the principal cells that were displaced and compressed along the cellular body and lateral surfaces by the rosettes, the disruption of the apical junctions that continued to maintain the continuity of the epithelium cover until the rosette exploded into the lumen filled with macrophagic cells in degeneration (round cells).

\section{Discussion.}

Taking into account that the epididymis possesses a conspicuous resident macrophagic population (10-18\% of all interstitial cells), when an inflammatory chronic reaction as a spermatic granuloma is established along the epididymal tubule a considerable immune response can be expected. A strict interrelationship between the activation and mobilization of interstitial macrophagic cells and the modification of the organization and distribution of the different types of cells of the epididymal epithelium can be hypothesized.

The contemporary presence of lymphocytes and macrophages in the large lymphatic sinusoids of the deferential serous coat and their margination for migration were a result of the focal-immune response. The permeation of the epithelium with macrophages, lymphocytes and heterophils sustains the intraepithelial organization into mounds. The focal epithelial mounds express reactive (immunological) and adaptive (proliferative) responses to segmental obstruction of the lumen. In the distal epididymal epithelium principal (stereociliated), clear (holocrine) and basal cells are classically distributed. The renewal of clear cells is an object of debate, but, independently of their role and specific activity, the cycle of renewal proposed by Martan and Risley in 1963 in mated and unmated rats represents a guide for interpreting the different stages of maturation, the secretory cycle and the degranulation process with the loss of clear cell granular PAS-positivity. Focal growing mounds are reported to appear along the proximal vas deferens after vasectomy (Cooper et Hamilton, 1977) and Flickinger (1972) affirms that «alteractions after vasectomy consisted mainly of an accelerated accumulation of large masses of membranous material in certain columnar cells of the cauda epididymidis. These cells have been referred to as « clear », " foamy », " holocrine » and « light" cells by different authors".

In our experiments all the rats were unmated before the operation and then isolated without being exposed to female or sexual stimulus: the epithelium reacted to the organization of spermatic granuloma with an accelerated turnover of clear cells that appear immature, partially degranulated with faint PASpositivity and stratified into focal aggregates; the compact aspect of the epithelial mounds seems to express the perturbation of clear cell turnover in response to a chronic stimulus : the immune response occurred all during the permeation of the epithelium with macrophagic cells which aggregated into intraepithelial rosettes that continuously spilled into the lumen.

The cleaning function (le nettoyage) of the mobilized macrophagic cells was to return the epithelium to its normal appearance. 


\section{Conclusion.}

In the presence of a perturbating chronic stimulus at the level of the epididymal wall with partial obstruction (as a spermatic granuloma) the epididymal epithelium reacts with a consistent involvement of the clear cells and of the interstitial resident macrophagic population: the accelerated turnover of the clear cells represents the primum movens in the compact aspect of epithelial mound organization; the subsequent permeation of the epithelium with PAS-positive macrophagic cells is responsible for the organization into focal intraepithelial macrophagic rosettes that disrupt the epithelium, producing its spongy aspect and then exploding into the lumen, bringing the epithelium back to its normal configuration.

This newly described function of epithelium cleaning, sustained by the epididymal resident macrophagic population, permits the normal turnover of the cellular components to be reestablished and contributes to the recanalization process after complex microsurgical tubulo-vasostomies.

$5^{e}$ Congrès de la Société d'Andrologie de langue française, Paris, décembre 1987

Résumé. Les bourgeons épithéliaux dans le tubule épididymaire distal (zone 9) après différentes techniques de microchirurgie épididymo-déférentielle chez le rat.

Après microchirurgie épididymo-déférentielle chez le rat, les réactions histo-pathologiques du compartiment interstitiel de l'épididyme et de la paroi du tractus épididymaire de la zone 9, selon la technique de Zunke et Gossrau, montrent une mobilisation très active des cellules phagocytaires interstitielles. Elles paraissent participer à la formation de bourgeons épithéliaux particuliers, rencontrés spécialement dans les cas de réaction granulomateuse au niveau de l'anastomose. Les bourgeons montrent des aspects compacts et spongieux. Contrairement aux bourgeons compacts, les bourgeons spongieux présentent dans le centre des rosettes macrophagiques constituées par des cellules positives au PAS. La présence de la réaction granulomateuse au niveau de l'anastomose tubulo-déférentielle active la mobilisation et la réponse des macrophages interstitiels de l'épididyme; ces cellules participent à l'organisation des bourgeons spongieux avec fonction de nettoyage de l'épithélium ; au contraire les bourgeons compacts représentent probablement une perturbation du renouvellement des cellules épithéliales.

\section{References}

CHRISTENSEN A. K., 1975. Leydig cells, 57-94. In GREEP R. O., ASWOOD E. B., Handbook of physialogy, Section 7, vol. 5. Am. Physiol. Soc., Washington D.C

COOPER T. G., HAMILTON D. W., 1977. Observations on destruction of spermatozoa in the cauda epididymidis and proximal vas deferens of non-seasonal male mammals. Am. J. Anat., 149. 93-110.

FAWCETT D. W., NEAVES W. B., FLORES M. N., 1973. Comparative observations on intertubular lymphatics and the organization of the interstitial tissue of the mammalian testis. Biol. Reprod., 9, 500-532.

FLICKINGER C. J., 1972. Alterations in the fine structure of the rat epididymis after vasectomy. Anat. Rec., 173, 277-300. 
HUME D. A., HALPIN D., CHARLTON H., 1984. The mononuclear phagocyte system of the mouse defined by immunohistochemical location of antigen F4/80: Macrophages of endocrine organs. Proc. nat. Acad. Sci., U.S.A., 81, 4174-4177.

MARTAN J., RISLEY P. L., 1963. The epididymis of mated and unmated rats. J. Morph., 113, 1-15.

NIEMI M., SHARPE R. M., BROWN W. R. A., 1986. Macrophages in the interstitial tissue of the rat testis. Cell Tissue Res., 243, 337-344.

SUZUKI F., 1982. Microvasculature of the mouse testis and excurrent duct system. Am. J. Anat., 163, 309-325.

TRITTO G., MITOLO-CHIEPPA D., CARRATU M. R., PAGLIARULO A., PICCINNO A., DI RIENZO U., 1983. Valutazione farmacologica ed elettrica di campo dopo anastomosi tubulodeferenziale termino-terminale e latero-terminale in campo sperimentale. Atti Soc it. Urologia $56^{\circ}$ Congr., Verona, 477.482.

TRITTO G., MITOLO-CHIEPPA D., CARRATU M. R., PAGLIARULO A., BALACCO G., PICCINNO A., 1984. Valutazione farmacologica alfa-adrenergica e colinergica dopo sostituzione completa del deferente con segmento di tubulo epididimario nel ratto. Urologia, LI, 11, 177-183.

TRITTO G., MITOLO-CHIEPPA D., PICCINNO A., DI GIOVANNI V., CARRATU M. R., 1985 . Functional evaluation of new experimental model of microsurgical tubulo-vasostomy in rat. Urologv, XXV. 2, 165-170.

TRITTO G., LABATE M., DESANTIS S., TRITTO M. C., 1986. Morpho-functional correlates of the distal epididymal tubule (zone 9 ) after intraserous proximal hemi- or subtotal deferentectomy and tubulo-vasostomy in rat. $87^{e}$ Vers. Anat. Ges., VEB-Gustav Fischer Verlag, Jena, $1155-1158$.

TRITTO G., TRITTO M. C., LABATE M., DESANTIS S., 1987. A new principle in reconstructive microsurgery of the epididymis: the intraserous unfolding of the epididymal tubule. An experimental study. Progr. Androl. Chirur., Acta Med., Roma, 43-46.

ZUNKE von U., GOSSRAU R., 1981. Zur Morphologie und Zonengliederung des Nebenhodenganges der Ratte. Anat. Anz., 149, 409-424. 